\title{
Spółki handlowe a znowelizowana ustawa o kształtowaniu ustroju rolnego - uwagi z praktyki notarialnej
}

\section{Wprowadzenie}

Z dniem 26 czerwca 2019 r. znowelizowana została Ustawa z dnia 11 kwietnia 2003 r. o kształtowaniu ustroju rolnego ${ }^{1}$. Te długo oczekiwane zmiany miały ułatwić obrót nieruchomościami rolnymi przy jednoczesnym utrzymaniu ochrony prawidłowego wykorzystania zasobów ziemi rolnej i realizacji celów u.k.u.r., wymienionych w jej preambule ${ }^{2}$. Znowelizowano także wiele przepisów dotyczących sfery działania spółek handlowych, przede wszystkim w zakresie obrotu udziałami i akcjami spółek kapitałowych ${ }^{3}$.

Celem artykułu jest ocena wpływu wprowadzonych przepisów na obrót nieruchomościami rolnymi z udziałem spółek handlowych oraz na obrót akcjami i udziałami spółek kapitałowych będących

* Małgorzata Muszalska,dr, e-mail: malgorzata.muszalska44@gmail.com, https:// orcid.org/0000-0002-5104-587X.

${ }^{1}$ Tekst jedn. Dz.U. 2019, poz. 1362 ze zm., dalej „u.k.u.r.”. Zmiana nastąiła Ustawą z dnia 26 IV 2019 r. o zmianie ustawy o kształtowaniu ustroju rolnego oraz niektórych innych ustaw (Dz.U. 2019, poz. 1080).

${ }^{2}$ Zob. uzasadnienie do projektu ustawy, druk sejmowy nr 3298/VIII kadencja, s. 3.

${ }^{3}$ Trzeba nadmienić, że u.k.u.r. posługuje się nieprawidłowym pojęciem „spółki prawa handlowego", gdyż zgodnie z Ustawą z dnia 15 IX 2000 r. Kodeks spółek handlowych (tekst jedn. Dz.U. 2019, poz. 505 ze zm.), dalej „k.s.h.”, do której odsyła u.k.u.r. (art. 3a ust. $1 \mathrm{i}$ art. $3 \mathrm{~b}$ ust. 1) są to "spółki handlowe". Powyższe wynika już nawet z nazwy kodeksu (Kodeks spółek handlowych, a nie Kodeks spółek prawa handlowego). Żeby nie utrwalać tej błędnej terminologii, w dalszej części artykułu jest mowa o spółkach handlowych, celowo zatem niezgodnie z brzmieniem u.k.u.r. 
właścicielami nieruchomości rolnych, w szczególności zbadanie zagadnienia, czy przepisy te ułatwiają, czy utrudniają obrót $\mathrm{w}$ aspekcie praktycznym, w tym dokonywanie czynności notarialnych. Ponieważ spółki handlowe to nie tylko spółki kapitałowe, ale i osobowe, konieczne jest też przeanalizowanie oddziaływania nowych przepisów na spółki osobowe w przypadku zmiany lub przystąpienia nowego wspólnika do spółki osobowej będącej właścicielem nieruchomości rolnej.

Ze względu na to, że nowe przepisy oddziałują na spółki handlowe oraz na ich wspólników w trzech sferach, problematykę związaną z wprowadzonymi nowelą zmianami można podzielić na trzy części. Pierwsza dotyczy zagadnień związanych z nabywaniem prawa własności i użytkowania wieczystego nieruchomości rolnych przez spółki handlowe. Druga obejmuje najistotniejsze zagadnienie, którego w największym stopniu dotyczy nowelizacja, czyli prawo pierwokupu oraz prawo nabycia udziałów względnie akcji w spółkach kapitałowych przysługujących Krajowemu Ośrodkowi Wsparcia Rolnictwa (dalej "KOWR” lub „Krajowy Ośrodek”). Trzecia odnosi się do zagadnienia związanego z nabywaniem przez KOWR nieruchomości rolnych w przypadku zmiany wspólnika lub przystąpienia nowego wspólnika do spółki osobowej oraz w przypadku podjęcia przez spółkę akcyjną uchwały, o której mowa w art. 27 ust. 2 pkt 3a Ustawy z dnia 29 lipca 2005 r. o ofercie publicznej i warunkach wprowadzania instrumentów finansowych do zorganizowanego systemu obrotu oraz o spółkach publicznych ${ }^{4}$. Przepis ten odsyła do uchwały w sprawie ubiegania się o dopuszczenie akcji objętych prospektem emisyjnym do obrotu na rynku regulowanym.

\section{Nowelizacja przepisów w zakresie nabywania nieruchomości rolnych przez spółki handlowe}

Zgodnie z podstawową zasadą u.k.u.r. nabywcą nieruchomości rolnej powinien być rolnik indywidualny. $Z$ kolei rolnikiem indywidualnym, w myśl art. 6 ust. 1 u.k.u.r., może być wyłącznie osoba fizyczna, nigdy zatem nie będzie nim spółka handlowa. Skutkiem powyższego jest obowiązek uzyskania przez spółki handlowe zgody Dyrektora Generalnego KOWR na nabycie nieruchomości rolnej, wyrażonej w drodze decyzji administracyjnej (art. 2a ust. 4 u.k.u.r.), chyba że podmiot nabywający

${ }^{4}$ Tekst jedn. Dz.U. 2019, poz. 623 ze zm. 
może skorzystać z ustawowych wyłączeń wymienionych w art. 2a ust. 3 u.k.u.r., o których mowa jest dalej ${ }^{5}$. Ponadto warto na wstępie zaznaczyć, że zgodnie z definicją ustawową (art. 2 pkt 7 u.k.u.r.) przez „nabycie nieruchomości rolnej" należy rozumieć przeniesienie własności nieruchomości rolnej lub nabycie własności nieruchomości rolnej w wyniku dokonania czynności prawnej lub orzeczenia sądu albo organu administracji publicznej, a także innego zdarzenia prawnego, czyli pod każdym tytułem prawnym (np. w wyniku zawarcia umowy sprzedaży, zamiany, darowizny, przeniesienia własności w drodze datio in solutum czy wniesienia aportu oraz w drodze dziedziczenia). Tak szerokie ujęcie „nabywania” spowodowało, że ustawodawca jednocześnie wprowadził wiele wyjątków skutkujących odstąpieniem od obowiązku uzyskania zgody Dyrektora Generalnego KOWR na nabycie (art. 2a ust. 3 u.k.u.r.). Kilka z tych wyjątków wprowadzono analizowaną nowelizacją, a część z nich dotyczy właśnie spółek handlowych.

Po pierwsze, rozszerzono katalog spółek, które zgodnie z wymienioną nowela, podmiotowo, zostały zwolnione z obowiązku uzyskania powołanej zgody na nabycie. Są to:

1. spółka handlowa, której wyłącznym udziałowcem albo akcjonariuszem jest Skarb Państwa, będąca operatorem systemu przesyłowego albo posiadająca koncesję na przesyłanie paliw ciekłych, w rozumieniu Ustawy z dnia 10 kwietnia 1997 r. - Prawo energetyczne ${ }^{6}$ (art. 2a ust. 3 pkt 1) lit. ca) tiret pierwsze u.k.u.r.),

2. spółka handlowa, która jest operatorem systemu dystrybucyjnego gazowego w rozumieniu przywoływanej ustawy - Prawo energetyczne, $\mathrm{w}$ przypadku nabycia nieruchomości rolnej na cele związane $\mathrm{z}$ budową, modernizacją lub rozbudową systemu dystrybucyjnego gazowego (art. 2a ust. 3 pkt 1) lit. ca) tiret drugie u.k.u.r.),

3. spółka kapitałowa lub grupa kapitałowa, o których mowa w art. 1 ust. 1 Ustawy z dnia 18 marca 2010 r. o szczególnych uprawnieniach ministra właściwego do spraw energii oraz ich wykonywaniu w niektórych spółkach kapitałowych lub grupach kapitałowych prowadzących działalność w sektorach energii elektrycznej, ropy naftowej oraz paliw

${ }^{5}$ Na temat charakteru prawnego zgody jako decyzji administracyjnej zob. E. Kremer, Zgoda Prezesa Agencji Nieruchomości Rolnych jako przesłanka nabycia nieruchomości, „Studia Iuridica Lublinensia" 2017, t. 26, nr 1, s. 35-53; K. Marciniuk, Zgoda administracyjna jako przesłanka nabycia nieruchomości rolnej, w: Nieruchomości rolne w praktyce notarialnej, pod red. P. Księżaka, J. Mikołajczyk, Warszawa 2017, s. 119-146.

${ }^{6}$ Tekst jedn. Dz.U. 2019, poz. 755 ze zm. 
gazowych ${ }^{7}$, w przypadku nabycia nieruchomości rolnej na cele związane $\mathrm{z}$ budową, modernizacją lub rozbudową mienia określonego $\mathrm{w}$ art. 1 ust. 2 tej ustawy (art. 2a ust. 3 pkt 1) lit. cb) u.k.u.r.).

Powyższe spółki, zwane dalej na potrzeby tego artykułu spółkami bezpieczeństwa energetycznego, to np. Polskie Sieci Elektroenergetyczne S.A. $z$ siedzibą w Konstancinie Jeziornej, operator systemu przesyłowego elektroenergetycznego (KRS 197596) - jednoosobowa Spółka Skarbu Państwa, Polska Spółka Gazownictwa Sp. z o.o. z siedzibą w Tarnowie, operator systemu przesyłowego gazowego (KRS 374001) ${ }^{8}$ czy PERN S.A. z siedzibą w Płocku, jednoosobowa Spółka Skarbu Państwa posiadająca koncesję na przesyłanie paliw ciekłych (KRS 69559) ${ }^{9}$. Można powiedzieć, że powołane zwolnienia dotyczą podmiotów o charakterze publicznym, a nie prywatnym, ze względu na ich strukturę własnościową. Ustawodawca uczynił dla nich wyjątek (nabywanie nieruchomości rolnych bez zgody KOWR), aby nie blokować im wykonywania zadań, do których zostały powołane. Ponieważ jest to szczególne, podmiotowe zwolnienie, w aktach notarialnych trzeba wykazać, że mamy do czynienia z wyżej wymienioną spółką czy grupą kapitałową. Dlatego też z treści aktu notarialnego będącego podstawą nabycia nieruchomości rolnej przez spółki bezpieczeństwa energetycznego powinna wynikać wskazana w ustawie podstawa prawna działania danej spółki, np. któraś z wymienionych w przepisie ustaw, wydruk z Krajowego Rejestru Sądowego pobrany dla spółki, akty powołania osób reprezentujących, uchwały, koncesje, określenie udziału Skarbu Państwa, a jeżeli przepis tego wymaga, także cel, na realizację którego niezbędne jest nabycie nieruchomości ${ }^{10}$.

Po drugie, wprowadzono zwolnienia, które dotyczą wszystkich spółek, nie tylko publicznych, ale także o kapitale prywatnym - przede wszystkim zwolnienie z obowiązku uzyskania zgody w przypadku, gdy

${ }^{7}$ Tekst jedn. Dz.U. 2016, poz. 2012.

${ }^{8}$ W spółce tej $100 \%$ udziałów posiada notowana na giełdzie spółka Polskie Górnictwo Naftowe i Gazownictwo Spółka Akcyjna z siedzibą w Warszawie (KRS 0000059492), w której większość akcji przysługuje Skarbowi Państwa. Informacja ze strony https://notowania.pb.pl/instrument/PLPGNIG00014/pgnig/informacje-spolka (dostęp: 20 I 2020).

${ }^{9}$ Przed analizowaną nowelizacją zwolnieniem takim objęta już była spółka celowa, o której mowa w Ustawie z dnia 10 V 2018 r. o Centralnym Porcie Komunikacyjnym (art. 2a ust. 3 pkt 1 lit. g) u.k.u.r.), i to na mocy Ustawy z dnia 10 V 2018 r. o Centralnym Porcie Komunikacyjnym (Dz.U. 2018, poz. 1089).

${ }^{10}$ Co do nabywania nieruchomości rolnych przez wymienione spółki zob. też K. Maj, Nowelizacja ustawy o ksztattowaniu ustroju rolnego obowiazujaca od dnia 26 czerwca 2019 r., „Krakowski Przegląd Notarialny" 2019, nr 2, s. 67-69. 
nabycie nieruchomości rolnej następuje w wyniku podziału, przekształcenia bądź łączenia spółek handlowych (art. 2a ust. 3 pkt 11 u.k.u.r.). To bardzo istotna zmiana, która ułatwia i przyspiesza wymienione postępowania (brak obowiązku uzyskania wyżej wymienionej zgody Dyrektora Generalnego KOWR), przy zachowaniu kontroli następczej KOWR w postaci prawa nabycia nieruchomości uzyskanej przez spółkę w wyniku tychże postępowań. Prawo to przysługuje Skarbowi Państwa reprezentowanemu przez KOWR - po rejestracji przez sąd podziału, przekształcenia bądź połączenia (art. 4 ust. 1 pkt 4 lit. b) u.k.u.r. ). Szkoda tylko, że powyższe zwolnienie nie objęło przekształcenia przedsiębiorcy w spółkę. W tym wypadku nadal, co do zasady, potrzebna jest zgoda Dyrektora Generalnego KOWR na nabycie nieruchomości rolnej przez spółkę, która powstanie w drodze przekształcenia, a zatem przez podmiot, który nie istnieje $\mathrm{w}$ chwili, gdy ubiega się o wydanie na jego rzecz decyzji administracyjnej. Pozostawiono tu "kontrolę uprzednią", tzn. obowiązek uzyskania zgody Dyrektora Generalnego KOWR na nabycie, co wyłącza wskazane powyżej prawo nabycia nieruchomości przez KOWR (art. 4 ust. 4 pkt 2 lit. a) u.k.u.r.).

Po trzecie, wszyscy nabywcy, w tym spółki handlowe, korzystać mogą z nowych zwolnień z obowiązku uzyskania zgody Dyrektora Generalnego KOWR na nabycie nieruchomości, wprowadzonych analizowaną nowelą. A zatem, tak jak wszystkie inne podmioty, również spółki handlowe mogą nabywać bez zgody Dyrektora Generalnego KOWR nieruchomości o powierzchni mniejszej niż 1 ha. Ponadto wszystkie podmioty nabywać mogą nieruchomości rolne $\mathrm{w}$ toku postępowania egzekucyjnego i upadłościowego, w wyniku zniesienia współwłasności oraz działu spadku czy położone na obszarze górniczym lub terenie górniczym w rozumieniu Ustawy z dnia 9 czerwca 2011 r. - Prawo geologiczne i górnicze ${ }^{11}$, bez względu na kryterium obszarowe (art. 2a ust. 3 pkt 1a, ust. 9, ust. 10 i ust. 12 u.k.u.r.).

Poza ułatwieniami w obrocie nieruchomościami rolnymi o powierzchni do 1 ha, co ważne jest dla wszystkich nabywających podmiotów, najistotniejsze znaczenie dla spółek mają wprowadzone nowelą zwolnienia przy nabywaniu nieruchomości w toku postępowania egzekucyjnego i upadłościowego. Obowiązek uzyskania zgody Dyrektora Generalnego KOWR na nabycie nieruchomości w powyższych trybach znacznie komplikował i przedłużał wymienione postępowania,

11 Tekst jedn. Dz.U. 2019, poz. 868 ze zm. 
zwłaszcza w zakresie praktyki notarialnej przy zawieraniu umów sprzedaży w postępowaniu upadłościowym ${ }^{12}$.

Na marginesie można wskazać, że spółki korzystają również z wcześniej wprowadzonych zwolnień, takich jak nabywanie w toku postępowania restrukturyzacyjnego $\mathrm{w}$ ramach postępowania sanacyjnego, na podstawie art. 151 lub art. 231 Kodeksu cywilnego ${ }^{13}$, bądź jeżeli zbyły uprzednio nieruchomość rolną na cele związane z realizacją Inwestycji lub Inwestycji Towarzyszącej w rozumieniu Ustawy z dnia 10 maja 2018 r. o Centralnym Porcie Komunikacyjnym ${ }^{14}$ - w okresie 3 lat od dnia zawarcia umowy - albo zostały z niej wywłaszczone na te same cele, względnie jeżeli nabywcą jest spółka celowa, o której mowa w ustawie o Centralnym Porcie Komunikacyjnym ${ }^{15}$.

Co do problematyki związanej z nabywaniem nieruchomości przez spółki handlowe trzeba też podkreślić, że zgodnie z u.k.u.r. Skarbowi Państwa, reprezentowanemu przez KOWR, przysługuje ustawowe prawo pierwokupu ${ }^{16}$ albo prawo nabycia nieruchomości (art. 3 i art. 4 u.k.u.r.) w zależności od tego, czy nabycie nieruchomości następuje w drodze zawarcia umowy sprzedaży czy na podstawie innego tytułu prawnego. Prawa te nie przysługują w sytuacji wydania przez Dyrektora

${ }^{12}$ Wcześniej sytuację częściowo ratowały orzeczenia: uchwała Sądu Najwyższego (SN) z 18 V 2017 r., sygn. III CZP 13/17, Legalis nr 1604510; uchwała SN z 24 VIII 2017 r., sygn. III CZP 35/17, Legalis nr 1651538. Dotyczyły one jednak tylko postępowań wszczętych przed dniem 30 IV 2016 r., tj. przed wejściem w życie nowelizacji u.k.u.r. wprowadzonej Ustawą z dnia 14 IV 2016 r. o wstrzymaniu sprzedaży nieruchomości Zasobu Własności Rolnej Skarbu Państwa oraz zmianie niektórych ustaw (Dz.U. poz. 585 ze zm.). Interpretowały one przepisy intertemporalne w ten sposób, że do postępowań wszczętych przed wymienioną datą nie stosuje się przepisów u.k.u.r. w nowym brzmieniu.

${ }^{13}$ Ustawa z dnia 23 IV 1964 r. Kodeks cywilny (tekst jedn. Dz.U. 2020, poz. 1740), dalej "k.c.".

${ }^{14}$ Dz.U. 2018, poz. 1089 ze zm.

${ }^{15}$ Ponadto spółki jako podmioty nabywające, podobnie jak wszyscy pozostali nabywcy, mogą też korzystać z innych wprowadzonych nowelizacją zwolnień, tj. na podstawie art. 17 ust. 1 Ustawy z dnia 3 II 1995 r. o ochronie gruntów rolnych i leśnych (tekst jedn. Dz.U. 2017, poz. 1161), art. 125 ust. 3 Ustawy z dnia 21 VIII 1997 r. o gospodarce nieruchomościami (tekst jedn. Dz.U. 2019, poz. 270 ze zm.) czy na podstawie przywoływanej ustawy Prawo geologiczne i górnicze. Wszystkie one dotyczą szczególnych podstaw nabywania nieruchomości. Ogólnie można powiedzieć, że chodzi tu o ochronę praw zbywcy nieruchomości, który ma możliwość przeniesienia własności nieruchomości na nabywcę (w tym spółkę), zamiast domagać się od niego odszkodowania na wyżej wymienionych podstawach.

${ }^{16}$ Można też odnotować, że przy zawieraniu umowy sprzedaży prawo pierwokupu przysługuje także dzierżawcy zbywanej nieruchomości, zgodnie $z$ art. 3 ust. 1 u.k.u.r., na zasadach tam określonych. 
Generalnego KOWR zgody na nabycie nieruchomości, często zatem z tego właśnie wyłączenia korzystają spółki (odpowiednio art. 3 ust. 5 pkt 2 oraz 4 ust. 4 pkt 2 lit. a) u.k.u.r.). Nie korzystają natomiast z innych zwolnień w tym zakresie, przewidzianych odpowiednio $w$ art. 3 ust. 5 u.k.u.r. co do prawa pierwokupu i w art. 4 ust. 4 u.k.u.r. co do prawa nabycia, gdyż zwolnienia te są zwolnieniami podmiotowymi i nie dotyczą spółek, z wyjątkiem spółek bezpieczeństwa energetycznego oraz spółki celowej. Jeżeli bowiem nieruchomości rolne nabywają spółki bezpieczeństwa energetycznego albo Spółka celowa, wyłączone jest zarówno prawo pierwokupu, jak i prawo nabycia (art. 3 ust. 5 pkt 1 lit. ba), bb) i d) u.k.u.r. w odniesieniu do prawa pierwokupu i w art. 4 ust. 4 pkt 2 lit. e), f) i g) u.k.u.r. w odniesieniu do prawa nabycia).

Trzeba też podkreślić, że po nabyciu nieruchomości przez spółki handlowe związane są one obowiązkami z art. $2 b$ u.k.u.r., tj. nakazem prowadzenia gospodarstwa rolnego (jeżeli nieruchomość rolna weszła w jego skład) oraz zakazem zbywania i oddawania w posiadanie innym podmiotom nabytej nieruchomości rolnej przez okres co najmniej 5 lat od dnia nabycia ${ }^{17}$. Ograniczenia te mogą powodować utrudnienia w działalności gospodarczej prowadzonej przez spółki i powinny być brane pod uwagę przy nabywaniu nieruchomości. Uwagę na tę kwestię powinien zwrócić notariusz, np. poprzez zawarcie w akcie notarialnym stosownego pouczenia.

Analizowana nowelizacja spowodowała również, że podobnie jak inne podmioty, tak i spółki mogą bez powyższych ograniczeń zbyć lub oddać w posiadanie innym podmiotom nieruchomość nabytą $w$ wyniku dziedziczenia oraz działu spadku lub zapisu windykacyjnego czy położoną w granicach administracyjnych miasta (o powierzchni mniejszej niż 1 ha) albo na obszarze górniczym lub terenie górniczym w rozumieniu ustawy Prawo geologiczne i górnicze (art. 2 b ust. 4 pkt 2, 3 i 4 u.k.u.r.). Ponadto bez wspomnianych ograniczeń zbywać mogą podmiotom: (1) określonym $\mathrm{w}$ art. $2 \mathrm{~b}$ ust. 4 pkt 1 , tj. jednostce samorządu terytorialnego, Skarbowi Państwa lub działającemu na jego rzecz KOWR, państwowej lub samorządowej osobie prawnej (jeżeli nieruchomość

${ }^{17}$ Zgodę na wcześniejsze dokonanie wymienionych w przepisie czynności, w formie decyzji administracyjnej, wydaje Dyrektor Generalny KOWR w przypadkach uzasadnionych ważnym interesem nabywcy (spółki) lub interesem publicznym (art. 2b ust. 3 u.k.u.r.), a organem wyższego stopnia, w rozumieniu przepisów Kodeksu postępowania administracyjnego, w wymienionych sprawach jest minister właściwy do spraw rozwoju wsi (art. 2 b ust. 3a u.k.u.r.). 
rolna jest przeznaczona na cele publiczne określone w ostatecznej decyzji o lokalizacji inwestycji celu publicznego); (2) osobie, której została przyznana pomoc, o której mowa w art. 3 ust. 1 pkt 6 lit. a) Ustawy z dnia 20 lutego 2015 r. o wspieraniu rozwoju obszarów wiejskich z udziałem środków Europejskiego Funduszu Rolnego na rzecz Rozwoju Obszarów Wiejskich w ramach Programu Rozwoju Obszarów Wiejskich na lata 2014-202018, na podstawie art. 151 lub art. 231 k.c.; (3) spółkom bezpieczeństwa energetycznego ${ }^{19}$. Te wszystkie zwolnienia wprowadzone zostały w drodze analizowanej noweli u.k.u.r. Ułatwiają one obrót, lecz $\mathrm{w}$ niewielkim stopniu. $Z$ punktu widzenia praktyki notarialnej najważniejsze jest zwolnienie dotyczące nieruchomości położonych w granicach administracyjnych miast, o powierzchni mniejszej niż 1 ha, w szczególności dla deweloperów. Na marginesie można nadmienić, że art. 2 b u.k.u.r. po ostatniej nowelizacji wzbudza wiele wątpliwości interpretacyjnych ${ }^{20}$, dlatego wymaga kolejnych zmian. Można nawet zgłosić postulat uchylenia tego przepisu. $\mathrm{W}$ praktyce niepotrzebnie blokuje on rolników w rozporządzaniu nabytymi nieruchomościami rolnymi.

\section{Nowelizacja przepisów w zakresie prawa pierwokupu oraz prawa nabycia udziałów i akcji w spółkach kapitałowych}

W myśl przepisów u.k.u.r. przy zbywaniu akcji i udziałów w spółce kapitałowej, tj. spółce z ograniczoną odpowiedzialnością i spółce akcyjnej, Krajowemu Ośrodkowi działającemu na rzecz Skarbu Państwa przysługuje prawo pierwokupu, jeżeli zbycie udziałów następuje w drodze zawarcia umowy sprzedaży (art. 3a ust. 1 u.k.u.r.), względnie prawo nabycia przy przeniesieniu praw do udziałów w wyniku dokonania innej czynności prawnej niż umowa sprzedaży lub w drodze orzeczenia albo zdarzenia prawnego (art. 4 ust. 6 u.k.u.r.) $)^{21}$.

18 Tekst jedn. Dz.U. 2018 r., poz. 627 ze zm.

${ }^{19} \mathrm{Na}$ temat problemów interpretacyjnych związanych $\mathrm{z}$ art. $2 \mathrm{~b}$ w przypadku utraty przez nieruchomość charakteru rolnego w rozumieniu u.k.u.r. zob. J. Bieluk, Ustawa o ksztattowaniu ustroju rolnego, wyd. 2, Warszawa 2019, s. 186-189; K. Maj, Nowelizacja ustawy o kształtowaniu ustroju rolnego..., s. 80; A. Bieranowski, Uwagi o błędnym dekodowaniu zakazu zbywania własności nieruchomości rolnej, "Rejent” 2019, nr 8, s. 110-117.

${ }^{20}$ P. Bender, Podstawowe problemy stosowania znowelizowanej ustawy o kształtowaniu ustroju rolnego (cz. 2), „Rejent” 2019, nr 12, s. 44-101.

${ }^{21}$ Powyższe dotyczy oczywiście również nabywania udziałów lub akcji w drodze podwyższenia kapitału zakładowego. Co do wcześniejszych problemów w tym zakresie 
Zgodnie z analizowaną w niniejszym artykule nowelizacją w obu przypadkach wprowadzono kilka zmian. Przede wszystkim według aktualnego brzmienia powołanych wyżej przepisów wymienione prawa przysługują Krajowemu Ośrodkowi, jeżeli spółka handlowa, w której zbywane są udziały, jest właścicielem lub użytkownikiem wieczystym nieruchomości rolnej o powierzchni co najmniej 5 ha albo nieruchomości rolnych o łącznej powierzchni co najmniej 5 ha. Wprowadzono zatem normę obszarową ( $5 \mathrm{ha}$ ) oraz rozszerzono zakres przedmiotowy wymienionych przepisów o prawo użytkowania wieczystego, gdyż przed nowelizacją prawo pierwokupu oraz prawo nabycia dotyczyły tylko udziałów bądź akcji w spółkach będących właścicielami nieruchomości rolnych. Poza tym wydłużono termin wykonania przysługujących KOWR praw z jednego do dwóch miesięcy (art. 3a ust. 4 oraz art. 4 ust. 6 u.k.u.r.). Co jednak najważniejsze, wprowadzono szczegółową procedurę obowiązującą przy wykonywaniu prawa pierwokupu oraz prawa nabycia (art. 3a ust. 3-6 oraz art. 4 ust. 6 u.k.u.r.). W procedurze tej uczestniczy także notariusz, choć w ograniczonym zakresie.

W odniesieniu do roli notariusza trzeba podkreślić, że nie ma on obowiązków związanych z dokonywaniem czynności notarialnych $\mathrm{w}$ obrocie akcjami. Zbywanie akcji imiennych dokonuje się $\mathrm{w}$ formie pisemnej, poprzez pisemne oświadczenie na samej akcji lub w odrębnym dokumencie i przeniesienie posiadania tejże akcji (art. 339 k.s.h.), natomiast przy zbywaniu akcji na okaziciela wystarczy wydanie dokumentu akcji (art. 921 k.c.). Dokonywanie czynności notarialnych (poświadczenie własnoręczności podpisu ${ }^{22}$ ) odbywa się natomiast przy zbywaniu udziałów w spółce z ograniczoną odpowiedzialnością (forma pisemna z podpisem notarialnie poświadczonym - art. $180 \S 1$ k.s.h.), z tym zastrzeżeniem, że zbywanie udziałów w spółce z ograniczoną odpowiedzialnością zawartej przy wykorzystaniu wzorca umowy nie wymaga już uczestniczenia notariusza (forma elektroniczna - art. $180 \S 2$ k.s.h., np. kwalifikowany podpis elektroniczny). Obecnie zatem notariusz nie uczestniczy w obrocie akcjami i udziałami

w odniesieniu do spółki akcyjnej zob. J. Stranz, Wptyw nowelizacji ustawy o kształtowaniu ustroju rolnego na procedure podwyższenia kapitatu zakładowego spółki akcyjnej, „Przegląd Prawa Handlowego" 2016, nr 12, s. 5 i n.; J. Grykiel, Ograniczenia obrotu nieruchomościami rolnymi oraz prawami udziałowymi w spółkach po nowelizacji ustawy o kształtowaniu ustroju rolnego, "Monitor Prawniczy” 2016, nr 12, s. 626 i n.

${ }_{22}$ Artykul 96 pkt 1 Ustawy z dnia 14 II 1991 r. - Prawo o notariacie (tekst jedn. Dz.U. 2019, poz. 540 ze zm.). 
( $z$ wyjątkiem poświadczenia podpisów na umowie zbycia udziałów w spółce z o.o., niezawartej przy wykorzystaniu wzorca umowy), ale protokołuje zgromadzenia wspólników spółek z ograniczoną odpowiedzialnością oraz walne zgromadzenia akcjonariuszy, dlatego istotna jest jego wiedza co do osób uprawnionych do uczestniczenia w obradach. Zgodnie bowiem z art. 9 u.k.u.r. nabycie akcji i udziałów w spółce handlowej będącej właścicielem nieruchomości rolnej o powierzchni co najmniej 5 ha albo nieruchomości rolnych o łącznej powierzchni co najmniej 5 ha dokonane niezgodnie z przepisami ustawy jest nieważne. W szczególności nieważne jest dokonanie czynności prawnej bez zawiadomienia uprawnionego (KOWR) o przysługującym mu prawie pierwokupu lub prawie nabycia. Ważność nabycia udziałów lub akcji wpływa z kolei na ważność głosowania, a co za tym idzie - na ważność podjętych uchwał, np. w sprawie zbycia lub nabycia nieruchomości, odwołania i powołania zarządu, który będzie dokonywał kolejnych czynności. W związku z tym istotne jest, by notariusz, w miarę możliwości, czuwał nad bezpieczeństwem obrotu udziałami, a nawet akcjami. W myśl art. $1 \S 1$ ustawy Prawo o notariacie notariusz jest powołany do dokonywania czynności, którym strony są obowiązane lub pragną nadać formę notarialną (czynności notarialnych). Dlatego w praktyce notariusz, jeżeli jest taka wola stron, może uczestniczyć nawet $\mathrm{w}$ obrocie akcjami.

Jeżeli notariusz dokonuje czynności poświadczenia podpisu, bez względu na to, czy jest taki obowiązek czy tylko wola stron, nie jest zobowiązany do sprawdzenia, czy spółka jest właścicielem nieruchomości rolnych o powierzchni powyżej $5 \mathrm{ha}^{23}$, ale ze względu na wskazane skutki prawne może np. uzyskać od stron informację, czy spółka jest właścicielem lub użytkownikiem wieczystym nieruchomości rolnej o powierzchni powyżej 5 ha i wpisać ją do klauzuli poświadczeniowej (jako informację uzyskaną od stron), względnie zamieścić pouczenie o prawie pierwokupu czy nabycia udziałów przez KOWR w treści tejże

${ }^{23}$ Nie ma przepisu nakładającego na notariusza taki obowiązek. Zob. też uchwałę SN z 19 XI 2010 r., sygn. III CZP 82/10, OSNC 2010, nr 6, poz. 62. Obowiązek sprawdzenia, czy spółka, w której zbywane są udziały lub akcje, jest właścicielem bądź użytkownikiem wieczystym nieruchomości, występuje jedynie przy nabyciu udziałów lub akcji przez cudzoziemca (art. 99 § 3 i ustawy Prawo o notariacie w zw. z art. 8a ust. 1 pkt 1 Ustawy z dnia 24 III 1920 r. o nabywaniu nieruchomości przez cudzoziemców (tekst jedn. Dz. U. 2017, poz. 2278). 
klauzuli. Najlepszym jednak rozwiązaniem jest poproszenie strony, aby powyższą informację zawierała już umowa zbycia udziałów, na której poświadczane będą podpisy ${ }^{24}$.

Przechodząc do analizy nowej procedury związanej z nabywaniem udziałów w spółce będącej właścicielem lub użytkownikiem wieczystym nieruchomości rolnej o powierzchni co najmniej 5 ha albo nieruchomości rolnych o łącznej powierzchni co najmniej 5 ha, trzeba na wstępie podkreślić, że zawarcie umowy sprzedaży następuje pod warunkiem zawieszającym, że KOWR, działający na rzecz Skarbu Państwa, nie wykona prawa pierwokupu przysługującego zgodnie $z$ dyspozycją art. $3 a$ ust. 1 u.k.u.r. Po zawarciu wspominanej warunkowej umowy sprzedaży zbywający powinien zawiadomić o niej spółkę. Spółka z kolei zawiadamia o zawartej umowie KOWR, załączając wymagane przez art. $3 a$ ust. 4 pkt 1-5 u.k.u.r. dokumenty. Są to: wypisy z ewidencji gruntów i budynków dla wszystkich nieruchomości rolnych stanowiących własność lub użytkowanie wieczyste spółki, odpis księgi wieczystej lub zaświadczenie wydane na podstawie zbioru dokumentów prowadzonego dla zbywanej nieruchomości rolnej, lub informacja o numerze księgi wieczystej dostępnej w centralnej bazie danych ksiąg wieczystych, potwierdzone za zgodność z oryginałem bilans oraz rachunek zysków i strat spółki (za trzy ostatnie lata obrotowe), aktualna lista wspólników lub akcjonariuszy oraz umowa lub statut spółki, a także oświadczenie zarządu spółki o wysokości zobowiązań warunkowych (podlegające odpowiedzialności karnej art. 3 a ust. 6 u.k.u.r.).

Od dnia odbioru przez KOWR zawiadomienia o umowie rozpoczyna się bieg dwumiesięcznego terminu wykonania prawa pierwokupu. Krajowy Ośrodek może podjąć wówczas czynności kontrolne w spółce. Mają one na celu zbadanie sytuacji prawnej, faktycznej i ekonomicznej spółki, jej potencjału i przydatności do celów wskazanych w preambule

${ }^{24}$ Notariusz może też dokonać sprawdzenia w centralnej bazie danych ksiąg wieczystych, czy spółka nie jest właścicielem lub użytkownikiem wieczystym nieruchomości rolnej o powierzchni powyżej 5 ha, i spisać protokół przed dokonaniem czynności. Podstawą jest tu art. $36^{4}$ ust. 8 pkt 18 Ustawy z dnia 6 VII 1982 r. o księgach wieczystych i hipotece (tekst jedn. Dz.U. 2019, poz. 2204). Wydaje się jednak, że wobec braku obowiązku sprawdzenia powyższego przez notariusza korzystanie z tej kompetencji jest zbyt daleko idące. Co innego, gdy nabywcą udziałów jest cudzoziemiec, jak to wskazano w przypisie poprzednim. 
u.k.u.r. Zgodnie z art. 3a ust. 3 u.k.u.r. ma on prawo przeglądania ksiąg i dokumentów oraz żądania od spółki informacji dotyczących obciążeń i zobowiązań nieujętych w księgach i dokumentach ${ }^{25}$. Jeżeli KOWR korzysta z prawa pierwokupu, wysyła zobowiązanemu z prawa pierwokupu oświadczenie o wykonaniu prawa pierwokupu ${ }^{26}$ przesyłką poleconą nadaną za potwierdzeniem odbioru w placówce pocztowej operatora pocztowego $\mathrm{w}$ rozumieniu Ustawy z dnia 23 listopada 2012 r. - Prawo pocztowe ${ }^{27}$, a następnie publikuje powyższą informację na stronie podmiotowej w Biuletynie Informacji Publicznej Krajowego Ośrodka. To właśnie $\mathrm{z}$ chwilą tejże publikacji umowa sprzedaży zostaje zawarta (art. 3 ust. 11, do którego odsyła art. 3a ust. 4 u.k.u.r.). Jeżeli KOWR nie wykona przysługującego mu prawa pierwokupu, zbycie udziałów następuje $\mathrm{z}$ chwilą upływu terminu do wykonania prawa pierwokupu lub z chwilą złożenia przez KOWR oświadczenia o rezygnacji z tego prawa. W szczególności nie jest konieczne zawarcie umowy przenoszącej udziały. Może być ona zawarta w sytuacji, gdy jest przewidziana $\mathrm{w}$ umowie sprzedaży zawartej pod warunkiem ${ }^{28}$. Nie negując wprowadzonej przez ustawodawcę zmiany podmiotu zawiadamiającego o sprzedaży udziałów ze wspólnika na spółkę (można przyjąć, że zarząd spółki ma zawsze wiedzę, czy spółka jest właścicielem nieruchomości rolnych, a wspólnik może tej wiedzy nie mieć), krytycznie ocenić trzeba wprowadzoną procedurę zawiadamiania KOWR przez spółkę o zawartej umowie, i to z dwóch powodów. Po pierwsze, z powodu pogorszenia sytuacji prawnej wspólnika sprzedającego udziały. W przepisach brak bowiem terminu, w jakim spółka ma przygotować wyżej wymienione dokumenty i przesłać je do KOWR. Sprzedający udziały wspólnik nie ma wpływu na te działania i może jedynie czekać. Po drugie, z powodu pogorszenia sytuacji prawnej samej spółki, zwłaszcza jej zarządu. Przygotowanie dokumentów wymaga czasu, pieniędzy, a dodatkowo

${ }^{25}$ Zgodnie z brzmieniem przywołanego przepisu uzyskane przez KOWR informacje stanowią tajemnicę przedsiębiorstwa w rozumieniu art. 11 ust. 2 Ustawy z dnia 16 IV 1993 r. o zwalczaniu nieuczciwej konkurencji (tekst jedn. Dz.U. 2019, poz. 1010 ze zm.).

${ }^{26} \mathrm{~W}$ praktyce czyni to $\mathrm{w}$ formie aktu notarialnego, choć przepisy nie wymagają takiej formy (http://www.kowr.gov.pl, dostęp: 27 XII 2019). Jak wyżej wskazano, do zbycia udziałów w spółce z ograniczoną odpowiedzialnością wymagana jest forma pisemna z podpisem notarialnie poświadczonym, a nie forma aktu notarialnego.

${ }^{27}$ Tekst jedn. Dz.U. 2018, poz. 2188 ze zm.

${ }^{28}$ Za zasadnością sporządzania dwóch umów (warunkowej oraz przenoszącej prawo do udziałów) opowiada się natomiast J. Bieluk, op. cit., s. 243. 
obwarowane jest odpowiedzialnością karną. Ogólnie przepisy te można ocenić jako przepisy „z poprzedniej epoki”. W czasach dokumentów elektronicznych ustawodawca wymaga gromadzenia dokumentów papierowych przez spółkę, gdy dostęp do owych dokumentów, w wersji elektronicznej, ma już KOWR ${ }^{29}$. Natomiast wszystkie inne, niewynikające z dokumentów elektronicznych, informacje może uzyskać w toku wspomnianych czynności kontrolnych. Stąd trzeba zgłosić postulat uchylenia nowych obowiązków gromadzenia papierowych dokumentów przez zarząd spółki w celu przekazania ich do KOWR, przy zachowaniu obowiązku zawiadomienia KOWR o zawartej umowie przez spółkę, a nie przez zbywającego wspólnika. Najważniejsze jest jednak uzupełnienie w przepisie terminu, w jakim spółka jest zobowiązana zawiadomić KOWR o doręczonej jej przez wspólnika umowie, by chronić prawa zbywającego wspólnika i umożliwić mu sprawne zbycie przysługujących mu praw.

Zgodnie z treścią analizowanej noweli zmiany dotyczą też ceny sprzedaży udziałów i akcji, a przede wszystkim jej zapłaty. W myśl art. 3a ust. 3a oraz art. 3a ust. 4 i zawartego w nim odesłania do art. 3 ust. 8a u.k.u.r., w przypadku gdy udziały są obciążone prawem zastawu, KOWR dokonuje zapłaty ceny w terminie $14 \mathrm{dni}$ od dnia otrzymania zawiadomienia o wygaśnięciu zastawu, o ile zapłata ceny jest już wymagalna. KOWR nie ma zatem możliwości dokonania zapłaty do rąk wierzyciela z tytułu zastawu. Nie jest to dobra regulacja, w sytuacji gdy zbywca nie ma środków na spłatę wierzytelności, a wierzyciel nie chce współpracować np. w znalezieniu innego zabezpieczenia. Właściwie może to zablokować sprzedaż. W tej sytuacji notariusz może zaproponować

${ }^{29}$ Przede wszystkim KOWR, podobnie jak notariusz, ma uprawnienie do sprawdzenia w centralnej bazie ksiąg wieczystych, ile i jakich nieruchomości ma dana spółka oraz jakie są numery ich ksiąg wieczystych (podstawą jest tu art. $36^{4}$ ust. 8 pkt 19 Ustawy o księgach wieczystych i hipotece). Jeżeli KOWR będzie miał numery ksiąg wieczystych, może wystąpić o wydanie wypisu z rejestru gruntów oraz budynków dla wszystkich nieruchomości (papierowych lub elektronicznych) zgodnie $\mathrm{z}$ art. 24 Ustawy z dnia 17 V 1989 r. Prawo geodezyjne i kartograficzne (tekst jedn. Dz.U. 2020, poz. 2052). Z kolei wgląd do dokumentów finansowych wszystkich spółek jest jawny, bezpłatny i dostępny na stronie https:/ekrs.ms.gov.pl („Przeglądarka dokumentów finansowych”). W wyszukiwarce tej, również po numerze KRS danej spółki, można sprawdzić listę wspólników czy akcjonariuszy. Co do akcjonariuszy po dematerializacji akcji, o czym poniżej, ustalenie listy akcjonariuszy będzie jeszcze prostsze. W trakcie postępowania kontrolnego KOWR może zweryfikować zebrane dokumenty i dane oraz uzupełnić je o informacje dotyczące wysokości warunkowych zobowiązań spółki, jak i zapoznać się z umową czy statutem spółki. 
wpisanie do umowy postanowienia, na podstawie którego KOWR będzie mógł zapłacić część ceny odpowiadającą wysokości zabezpieczonej wierzytelności na rachunek wierzyciela podany w umowie.

Pozytywnie natomiast należy ocenić wprowadzone nowelą rozwiązanie, że jeżeli cena rażąco odbiega od wartości rynkowej, wykonujący prawo pierwokupu (KOWR) może, w terminie 14 dni od dnia złożenia oświadczenia o wykonaniu prawa pierwokupu, wystąpić do sądu o ustalenie ceny, płacąc jednocześnie niesporną część ceny przed wystąpieniem do sądu o ustalenie ceny.

Ponadto w drodze nowelizacji rozszerzono katalog podmiotów mogących nabyć udziały z pominięciem prawa pierwokupu. Oprócz osób bliskich i Skarbu Państwa, a także zwolnienia podmiotowego spółek, których akcje są dopuszczone do obrotu zorganizowanego w rozumieniu Ustawy z dnia 29 lipca 2005 r. o obrocie instrumentami finansowymi $^{30}$, wymieniono tu spółki bezpieczeństwa energetycznego. Nadal jednak zwolnieniem tym nie objęto takich nabywców jak jednostki samorządu terytorialnego, rolnicy indywidualni i dotychczasowi wspólnicy ani nabywania udziałów czy akcji w celu ich umorzenia, co od dawna jest postulowane $w$ literaturze ${ }^{31}$.

Ze względu na to, że przy wykonywaniu przez KOWR prawa nabycia ustawodawca zastosował tę samą procedurę jak przy wykonywaniu prawa pierwokupu (poprzez stosowne odesłanie w art. 4 ust. 6 u.k.u.r.), bezcelowe jest ponowne jej omawianie. Można jedynie podkreślić kilka najistotniejszych kwestii.

Po pierwsze, zawarcie umowy (oczywiście innej niż umowa sprzeda$\dot{z} y$, np. darowizny czy zamiany) następuje bezwarunkowo. W przypadku nabycia udziałów w wyniku podwyższenia kapitału zakładowego zawiadomienia KOWR dokonuje spółka, po wpisaniu tego podwyższenia do rejestru przedsiębiorców prowadzonego na podstawie przepisów o Krajowym Rejestrze Sądowym (art. 4 ust. 6 zd. 2 u.k.u.r.). Po drugie, ze względu na możliwość nabywania udziałów czy akcji pod różnymi tytułami prawnymi (nie tylko umowy) ustawodawca w art. 4 ust. 5 u.k.u.r. wskazał podmioty, na których w określonej sytuacji ciąży obowiązek zawiadomienia spółki o zbyciu udziałów. Takim podmiotem jest przede wszystkim nabywca, ale także sąd, organ administracji publicznej czy organ egzekucyjny. Po trzecie, jeżeli chodzi o prawo nabycia, nieważność

\footnotetext{
${ }^{30}$ Tekst jedn. Dz.U. 2020, poz. 89 ze zm.

${ }^{31} \mathrm{~K}$. Maj, Zmiany w ustawie o kształtowaniu ustroju rolnego obowiazujace od dnia 30 kwietnia 2016 r., „Krakowski Przegląd Notarialny” 2016, nr 2, s. 94.
} 
czynności może być związana tylko z brakiem zawiadomienia KOWR o czynności w celu wykonania prawa nabycia. Na notariuszu nie ciąży obowiązek informowania KOWR o czynności. Obowiązek ten spoczywa na spółce, tak jak przy prawie pierwokupu (odesłanie w art. 4 ust. 6 do art. $3 a$ ust. 4 u.k.u.r.). Również w tym przypadku dokonujący czynności notariusz nie ma obowiązku badania, czy spółka jest właścicielem lub użytkownikiem wieczystym nieruchomości rolnych. Wskazane jest jednak zamieszczenie pouczeń o uprawnieniu do nabycia udziałów przez KOWR w treści klauzuli poświadczeniowej bądź w umowie, jeżeli jest ona zawierana w formie aktu notarialnego.

Można jeszcze wskazać kilka ważnych zagadnień związanych z analizowaną problematyką. Przede wszystkim, w przypadku zbiegu pierwokupów: umownego (dla wspólnika z umowy spółki) oraz ustawowego dla KOWR - pierwszeństwo ma KOWR ${ }^{32}$. Istotne jest też wykonywanie prawa głosu w okresie pomiędzy zawarciem umowy zbycia a nabyciem udziałów przez KOWR. W przypadku zawarcia umowy warunkowej sprzedaży (gdy KOWR przysługuje prawo pierwokupu) prawo głosu i inne przypadające na udziały uprawnienia, do dnia wykonania prawa pierwokupu przez KOWR lub do dnia upływu terminu jego wykonania - przysługują sprzedającemu. Jeżeli ze względu na zawarcie umowy sprzedaży nie chciałby on już uczestniczyć w spółce, może np. udzielić pełnomocnictwa nabywcy udziałów, żeby ten mógł już brać udział w decydowaniu o sprawach spółki, choć jeszcze w imieniu i na rzecz sprzedającego, a nie w imieniu własnym. W przypadku zawarcia umowy bezwarunkowej (gdy KOWR przysługuje prawo nabycia) uprawnienia te, od dnia zawarcia umowy zbycia do dnia wykonania przez KOWR prawa nabycia udziałów, wykonuje nabywca. W tej sytuacji jest zatem odwrotnie. Nabywca od razu działa w imieniu własnym i na własna rzecz, do czasu aż KOWR nie wykona prawa nabycia. Warto też podkreślić, że zgodnie z dyspozycją nowego art. 4c u.k.u.r. w przypadku wykonywania prawa pierwokupu oraz prawa nabycia przez KOWR przepisy art. 600 k.c. stosuje się również do postanowień umowy spółki z ograniczoną odpowiedzialnością i statutu spółki akcyjnej ${ }^{33}$.

${ }^{32}$ S. Byczko, Ustawowe prawo pierwokupu udziałów i akcji spółek będacych właścicielami nieruchomości rolnych, w: Nieruchomości rolne..., s. 240. Natomiast jeżeli z umowy spółki wynika prawo pierwszeństwa dla wspólnika, nie ma kolizji. Jest ono wykonywane zawsze przed prawem pierwokupu czy to dla wspólnika, czy dla KOWR.

${ }_{33}$ Zgodnie z tym przepisem: $\S 1$. Przez wykonanie prawa pierwokupu dochodzi do skutku między zobowiązanym a uprawnionym umowa sprzedaży tej samej treści 
W odniesieniu do obrotu akcjami trzeba jeszcze nadmienić, że na wejście w życie oczekują dwie nowele Kodeksu spółek handlowych: zgodnie z Ustawą z dnia 19 lipca 2019 r. o zmianie ustawy - Kodeks spółek handlowych oraz niektórych innych ustaw ${ }^{34}$ oraz Ustawą z dnia 30 sierpnia 2019 r. o zmianie ustawy - Kodeks spółek handlowych oraz niektórych innych ustaw ${ }^{35}$. Pierwsza wprowadzi nowy rodzaj spółki prostą spółkę akcyjną ${ }^{36}$, której akcje będą od początku zdematerializowane (bez formy dokumentu), druga natomiast obejmuje obowiązek dematerializacji akcji wszystkich istniejących spółek akcyjnych oraz spółek komandytowo-akcyjnych. Nowelizacje planują wprowadzenie tzw. rejestru akcjonariuszy, za pomocą którego będzie się odbywał obrót akcjami zdematerializowanymi (chwila wpisu w rejestrze akcjonariuszy to chwila nabycia akcji, odpowiednio art. $328^{9} \mathrm{i}$ art. $300^{36} \mathrm{k}$.s.h.). Celem jest, aby wszystkie akcje uzyskały charakter imienny i aby zawsze było wiadomo, kto $\mathrm{w}$ danym dniu jest akcjonariuszem spółki. Zmiany przewidują też formę dokumentową jako właściwą dla obrotu akcjami, lecz nie nowelizują u.k.u.r. Oznacza to, że nadal na zbywcy będzie spoczywał obowiązek zawiadomienia spółki o transakcji w celu skierowania do KOWR zawiadomienia o przysługującym Skarbowi Państwa prawie pierwokupu lub prawie nabycia akcji (art. 3a ust. 4 i art. 4 ust. 6 u.k.u.r.). Zmieni się tylko chwila nabycia przez KOWR akcji w drodze wykonania prawa pierwokupu lub prawa nabycia. Obecnie, jak to wyżej wskazano, nabycie następuje z chwilą publikacji w Biuletynie Informacji Publicznej Krajowego Ośrodka oświadczenia KOWR o skorzystaniu z wymienionych praw, po wejściu w życie nowych przepisów nastąpi zaś ono z chwilą rejestracji w rejestrze akcjonariuszy nowego akcjonariusza - KOWR.

Można jeszcze nadmienić, że rejestr akcjonariuszy w odniesieniu do prostej spółki akcyjnej będzie mógł prowadzić notariusz mający

co umowa zawarta przez zobowiązanego z osobą trzecią, chyba że przepis szczególny stanowi inaczej. Jednakże postanowienia umowy z osobą trzecią mające na celu udaremnienie prawa pierwokupu są względem uprawnionego bezskuteczne; § 2. Jeżeli umowa sprzedaży zawarta z osobą trzecią przewiduje świadczenia dodatkowe, których uprawniony do pierwokupu nie mógłby spełnić, może on swe prawo wykonać, uiszczając wartość tych świadczeń. Jednakże gdy prawo pierwokupu przysługuje Skarbowi Państwa lub jednostce samorządu terytorialnego z mocy ustawy, takie świadczenie dodatkowe uważa się za niezastrzeżone.

${ }^{34}$ Dz.U. 2019, poz. 1655.

${ }^{35}$ Dz.U. 2019, poz. 1798.

${ }^{36} \mathrm{Na}$ temat prostej spółki akcyjnej zob. M. Celichowski, Krótkie omówienie prostej spótki akcyjnej, "Rejent" 2020, nr 8, s. 31 i n. 
kancelarię notarialną na terenie Rzeczypospolitej (art. $300^{31}$ k.s.h.), po zawarciu ze spółką umowy o prowadzenie rejestru jej akcjonariuszy (art. 108a k.s.h.). Dlatego przed dokonaniem wpisu będzie kontrolował, czy obrót akcjami nastąpił zgodnie z prawem, w tym z u.k.u.r. Zachowują aktualność wcześniej zgłoszone uwagi co do postępowania notariusza w tym zakresie, z uwzględnieniem obowiązku, który wyrażony będzie wprost $\mathrm{w}$ art. $300^{33} \S 5$ i 6 k.s.h. W myśl tego przepisu podmiot prowadzący rejestr akcjonariuszy bada treść i formę dokumentów uzasadniających dokonanie wpisu. Podmiot ten nie ma jednak obowiązku badania zgodności z prawem oraz prawdziwości dokumentów uzasadniających dokonanie wpisu, w tym podpisów zbywcy akcji lub osób ustanawiających ograniczone prawo rzeczowe na akcji, chyba że poweźmie w tym względzie uzasadnione wątpliwości (§ 5). Przy dokonywaniu wpisów do rejestru akcjonariuszy podmiot prowadzący rejestr uwzględnia ograniczenia co do rozporządzania akcją (\$ 6). Bada zatem również "ograniczenia ustawowe”, w tym wynikające $z$ u.k.u.r. czy z ustawy o nabywaniu nieruchomości przez cudzoziemców. Pozostałe podmioty, które będą prowadzić rejestr akcjonariuszy (w tym akcji prostej spółki akcyjnej), przed dokonaniem wpisu do tego rejestru także powinny zbadać powyższe (np. czy zbywca zawiadomił spółkę będącą właścicielem nieruchomości rolnych o transakcji, czy spółka zawiadomiła o niej KOWR albo czy nastapiło wykonanie przez KOWR prawa pierwokupu lub nabycia, czyli publikacja w Biuletynie Informacji Publicznej Krajowego Ośrodka). Podkreślenia wymaga to, że obowiązki notariusza dotyczyć będą jedynie akcji prostej spółki akcyjnej, z którą notariusz zawarł umowę o prowadzenie rejestru akcjonariuszy. Akcjonariusze i akcje pozostałych spółek akcyjnych oraz komandytowo-akcyjnych będą wpisywani w rejestrze akcjonariuszy przez inne, ustawowo wskazane podmioty ${ }^{37}$. Czas pokaże, w jaki sposób poradzą sobie one $z$ badaniem i stosowaniem powołanych ustawowych ograniczeń w rozporządzaniu akcjami spółek będących właścicielami nieruchomości rolnych o powierzchni co najmniej 5 ha.

Obie wskazane zmiany k.s.h. wejdą w życie 1 marca 2021 r. zgodnie z treścią przywoływanych nowelizacji.

${ }^{37}$ Chodzi o podmioty, o których mowa w ustawie o obrocie instrumentami finansowymi, uprawnione do prowadzenia rachunków papierów wartościowych. 


\section{Nowelizacja przepisów dotyczących nabywania nieruchomości rolnych przez KOWR w przypadku zmiany wspólnika lub przystąpienia nowego wspólnika do spółki osobowej}

Co do spółek osobowych należy na wstępie podkreślić, że już przed analizowaną nowelizacja, w myśl art. $3 b$ ust. 1 u.k.u.r., w przypadku zmiany wspólnika lub przystąpienia nowego wspólnika do spółki osobowej w rozumieniu k.s.h., która była właścicielem nieruchomości rolnej, Krajowy Ośrodek działający na rzecz Skarbu Państwa mógł złożyć oświadczenie o nabyciu tej nieruchomości za zapłatą równowartości pieniężnej odpowiadającej jej wartości rynkowej. Nowelą rozszerzono zakres przedmiotowy przepisu o prawo użytkowania wieczystego oraz wprowadzono minimalną normę obszarową - 5 ha gruntów, których właścicielem bądź użytkownikiem wieczystym powinna być spółka osobowa, tak samo zatem jak w przypadku spółek kapitałowych.

Zgodnie $\mathrm{z}$ aktualnym brzmieniem art. $3 \mathrm{~b}$ ust. 1 u.k.u.r. w przypadku zmiany wspólnika lub przystąpienia nowego wspólnika do spółki osobowej w rozumieniu k.s.h., która jest właścicielem lub użytkownikiem wieczystym nieruchomości rolnej o powierzchni co najmniej 5 ha albo nieruchomości rolnych o łącznej powierzchni co najmniej 5 ha, Krajowy Ośrodek działający na rzecz Skarbu Państwa może złożyć oświadczenie o nabyciu tych nieruchomości za zapłatą ceny odpowiadającej ich wartości rynkowej ${ }^{38}$. Ponieważ nie jest to przystąpienie do spółki jak w przypadku spółek kapitałowych, ale jedynie nabycie nieruchomości spółki, procedura jest znacznie mniej skomplikowana i w zasadzie nie została zmieniona w trakcie ostatniej nowelizacji.

Rozpoczyna się ona powiadomieniem KOWR przez spółkę o zmianie bądź przystąpieniu nowego wspólnika do tej spółki w terminie miesiąca od dnia dokonania czynności prawnej, w wyniku której nastąpiła zmiana bądź przystąpienie wspólnika. Do powiadomienia spółka dołącza tylko wypis z ewidencji gruntów i budynków każdej nieruchomości rolnej spółki ${ }^{39}$. Z kolej KOWR określa wartość rynkową nieruchomości przy zastosowaniu sposobów określenia wartości

\footnotetext{
${ }^{38}$ Nowelizacja zmieniła też określenie „równowartość pieniężna” na "cena odpowiadająca wartości rynkowej", co zgodne jest z terminologią przyjętą w ustawie o gospodarce nieruchomościami, do której przepis odsyła.

${ }^{39}$ Oczywiście przepis ten jest zbędny, gdyż - jak to wyżej wskazano - dokumenty te może uzyskać KOWR, i to zarówno w wersji elektronicznej, jak i papierowej.
} 
nieruchomości przewidzianych w przepisach o gospodarce nieruchomościami i jeżeli jest zainteresowany nabyciem nieruchomości, wysyła spółce oświadczenie, w formie aktu notarialnego, o wykonaniu prawa nabycia, a następnie publikuje wymienione oświadczenie na stronie podmiotowej w Biuletynie Informacji Publicznej Krajowego Ośrodka. Podobnie jak przy nabywaniu udziałów, chwila nabycia nieruchomości przez KOWR to chwila publikacji w Biuletynie Informacji Publicznej Krajowego Ośrodka (art. 3 ust. 11, do którego odsyła art. 3 b ust. 5 u.k.u.r.). Spółka w terminie miesiąca od dnia otrzymania oświadczenia KOWR o nabyciu nieruchomości rolnej może wystąpić do sądu o ustalenie ceny odpowiadającej wartości rynkowej nieruchomości rolnej nabytej przez KOWR. W drodze analizowanej nowelizacji dodano ust. 4a w art. 3b u.k.u.r., zgodnie z którym sąd ustala cenę odpowiadającą wartości rynkowej nieruchomości rolnej przy zastosowaniu sposobów określenia wartości nieruchomości przewidzianych w przepisach o gospodarce nieruchomościami.

Kończąc tę część rozważań, można jeszcze nadmienić, że notariusz w odniesieniu do spółek osobowych uczestniczy w zawiązaniu spółki komandytowej i komandytowo-akcyjnej (forma aktu notarialnego odpowiednio art. 106 i art. 131 k.s.h.) oraz przy zmianie umów wyżej wymienionych spółek, co może dotyczyć przystąpienia wspólnika, wystąpienia wspólnika, zmiany umowy spółki po zmianie wspólnika w drodze nabycia ogółu praw i obowiązków w spółce ${ }^{40}$. Także w tej sytuacji na notariuszu nie ciąży obowiązek informowania KOWR o dokonaniu czynności notarialnej. Obowiązek ten spoczywa na spółce (art. 3b ust. 3 u.k.u.r.). Ze względu na bezpieczeństwo obrotu i grożącą nieważność czynności (art. 9 ust. 1 pkt 1 u.k.u.r.) wskazane jest zamieszczenie pouczeń o uprawnieniu do nabycia nieruchomości przez KOWR w treści aktu notarialnego lub w klauzuli poświadczeniowej ${ }^{41}$.

\footnotetext{
${ }^{40}$ Natomiast wypowiedzenie umowy spółki oraz przeniesienie ogółu praw i obowiązków wspólnika w spółce osobowej nie wymaga formy aktu notarialnego.

${ }^{41} \mathrm{Na}$ marginesie można jeszcze nadmienić, że KOWR nie przysługuje prawo nabycia nieruchomości zgodnie z art. 3b ust. 6 u.k.u.r., jeżeli zamiast dotychczasowego wspólnika wspólnikiem staje się osoba mu bliska oraz jeżeli nowym wspólnikiem staje się osoba bliska któregokolwiek ze wspólników. Ta regulacja prawna obowiązywała już przed nowelizacją i nie uległa zmianie. Można też podkreślić, że wyłączenie, podobnie jak to jest w odniesieniu do spółek kapitałowych, nie obejmuje sytuacji, gdy nabywa rolnik indywidualny. Innymi słowy, również wtedy KOWR przysługuje prawo nabycia. Jest natomiast wątpliwe, czy prawo to przysługuje w przypadku zmiany wspólnika w drodze dziedziczenia. Za taką interpretacją opowiada się J. Bieluk, op. cit., s. 258-259.
} 


\section{Nowe prawo nabycia}

W trakcie omawianej nowelizacji do u.k.u.r. dodany został art. 3c, zgodnie z którym w przypadku podjęcia przez spółkę akcyjna, która jest właścicielem lub użytkownikiem wieczystym nieruchomości rolnej o powierzchni co najmniej 5 ha albo nieruchomości rolnych o łącznej powierzchni co najmniej 5 ha, uchwały, o której mowa w art. 27 ust. 2 pkt 3a ustawy o ofercie publicznej i warunkach wprowadzania instrumentów finansowych do zorganizowanego systemu obrotu oraz o spółkach publicznych, KOWR może złożyć oświadczenie o nabyciu tych nieruchomości za zapłatą ceny odpowiadającej ich wartości rynkowej określonej przy zastosowaniu sposobów określenia wartości nieruchomości przewidzianych w przepisach o gospodarce nieruchomościami. Powołany art. 27 ust. 2 pkt 3a dotyczy uchwały w sprawie ubiegania się o dopuszczenie akcji objętych prospektem emisyjnym do obrotu na rynku regulowanym. Wprowadzenie nowej regulacji do u.k.u.r. daje możliwość nabycia nieruchomości spółki akcyjnej przez KOWR, zanim jej akcje zostaną dopuszczone do obrotu zorganizowanego, bo wtedy obrót nimi będzie podlegał zwolnieniu z art. 3a ust. 1 pkt 1 u.k.u.r.

Tak jak przy nabywaniu nieruchomości spółek osobowych, tak i w tym przypadku (przepis dotyczy nabywania nieruchomości, a nie akcji) można powiedzieć, że ustawodawca zastosował "procedurę uproszczoną". Reguluje ją art. 3b ust. 2-5 u.k.u.r. Powołana spółka akcyjna jest mianowicie obowiązana powiadomić Krajowy Ośrodek o uchwale, o której mowa w przepisie, w terminie miesiąca od dnia jej podjęcia. Do tego powiadomienia dołącza wypis z ewidencji gruntów i budynków dla każdej nieruchomości rolnej stanowiącej własność spółki ${ }^{42}$. KOWR ustala cenę odpowiadającą wartości rynkowej określonej przy zastosowaniu sposobów określenia wartości nieruchomości przewidzianych w przepisach o gospodarce nieruchomościami. Jeżeli KOWR jest zainteresowany nabyciem nieruchomości, wysyła spółce oświadczenie, w formie aktu notarialnego, o wykonaniu prawa nabycia, a następnie publikuje wymienione oświadczenie na stronie podmiotowej w Biuletynie Informacji Publicznej Krajowego Ośrodka. Podobnie jak we wcześniej zanalizowanych

Odmienne twierdzi K. Maj, Nowelizacja ustawy o kształtowaniu ustroju rolnego..., s. 96, argumentujący, że przepis stanowi o zmianie wspólnika w drodze dokonania czynności prawnych, dlatego nie dotyczy dziedziczenia. Za taką interpretacją opowiada się też J. Grykiel, op. cit., s. 639.

${ }^{42}$ Zob. uwagi zamieszczone $\mathrm{w}$ przepisie poprzednim. 
przepisach, chwila nabycia nieruchomości przez KOWR to chwila publikacji w Biuletynie Informacji Publicznej Krajowego Ośrodka (art. 3 ust. 11, do którego odsyła art. 3c ust. 5 u.k.u.r.). Spółka w terminie miesiąca od dnia otrzymania oświadczenia KOWR o nabyciu nieruchomości rolnej może wystąpić do sądu o ustalenie ceny odpowiadającej wartości rynkowej nieruchomości rolnej nabywanej przez KOWR. Sąd ustala cenę odpowiadająca wartości rynkowej nieruchomości rolnej przy zastosowaniu sposobów określenia wartości nieruchomości przewidzianych w przepisach o gospodarce nieruchomościami.

\section{Podsumowanie}

Nowelizacja ustawy o kształtowaniu ustroju rolnego, która weszła w życie 26 czerwca 2019 r., wprowadziła wiele zmian odnoszących się do spółek handlowych. Pozytywnie należy ocenić ułatwienia w nabywaniu nieruchomości rolnych przez spółki - i to nie tylko te publiczne (spółki bezpieczeństwa energetycznego), ale przede wszystkim prywatne, zwłaszcza w nabywaniu nieruchomości w wyniku podziału, przekształcenia bądź łączenia spółek prawa handlowego, a także w toku postępowania egzekucyjnego i upadłościowego. W kwestii przekształceń można jeszcze raz zgłosić postulat, aby przy kolejnej nowelizacji przepis dotyczył też przekształcenia przedsiębiorcy w spółkę.

Dobrym rozwiązaniem jest również wprowadzenie normy obszarowej, zgodnie z którą Krajowemu Ośrodkowi działającemu na rzecz Skarbu Państwa przysługuje prawo pierwokupu lub prawo nabycia udziałów i akcji w spółce kapitałowej oraz prawo nabycia nieruchomości spółki osobowej w przypadku zmiany jej wspólnika lub przystąpienia do niej nowego wspólnika, jeżeli wymienione spółki handlowe są właścicielami lub użytkownikami wieczystymi nieruchomości rolnej o powierzchni co najmniej 5 ha albo nieruchomości rolnych o łącznej powierzchni co najmniej 5 ha. Powyższe kryterium obszarowe eliminuje wiele transakcji, które wcześniej były zawierane, a dotyczyły spółek nieprowadzących działalności rolniczej albo niewielkich, nieprzydatnych KOWR gruntów. Nowelizacja wprost przesądziła, że w wymienionych przypadkach regulacją objęte jest także prawo użytkowania wieczystego, co wcześniej budziło wątpliwości interpretacyjne.

Największa zmiana dotyczy wprowadzenia długiej i skomplikowanej procedury związanej z wykonywaniem przez KOWR prawa pierwokupu 
oraz prawa nabycia udziałów oraz akcji w spółkach kapitałowych. Choć czas na wykonanie przez KOWR jego uprawnień został wydłużony $\mathrm{z}$ jednego do dwóch miesięcy, to w rzeczywistości proces ten może trwać wiele miesięcy ze względu na niepotrzebny obowiązek zgromadzenia przez spółkę wielu papierowych dokumentów dla KOWR. Trzeba zgłosić postulat uchylenia tego obowiązku, gdyż KOWR ma dostęp do wymienionych dokumentów i może pobrać je w formie papierowej lub elektronicznej. Nowe przepisy wyposażyły KOWR w kompetencje kontrolne (badanie ksiąg i dokumentów spółki przed podjęciem decyzji o wykonaniu prawa pierwokupu czy prawa nabycia). KOWR ma zatem możliwość uzyskania od zarządu, w toku tej kontroli, wszystkich informacji potrzebnych do podjęcia decyzji, czy wykonać, czy nie wykonywać wymienionych praw, jeżeli informacje te nie wynikałyby z zebranych dokumentów albo gdyby dokumenty te nie były aktualne. Natomiast obowiązek gromadzenia dokumentów przez zarząd w formie papierowej w celu przekazania ich KOWR niepotrzebnie hamuje obrót akcjami oraz udziałami i negatywnie wpływa na sytuację prawną wspólników zbywających przysługujące im akcje czy udziały.

Pozytywnie natomiast należy ocenić zmianę w zakresie podmiotu zobowiązanego do zawiadomienia KOWR o przysługującym mu prawie pierwokupu czy nabycia, ze zbywającego wspólnika (przy umowie sprzedaży) oraz z nabywcy (przy innej podstawie nabycia) na spółkę. Tylko spółka ma pełną wiedzę co do swoich nieruchomości, ich rodzaju oraz powierzchni, dlatego tylko ona może ocenić, czy KOWR przysługują wymienione prawa. Wspólnik czy akcjonariusz takiej wiedzy może nie mieć. $Z$ drugiej jednak strony krytycznie należy ocenić brak ustawowego terminu dla spółki do zgromadzenia wymaganych przez u.k.u.r. dokumentów i zawiadomienia KOWR w celu wykonania jego prawa pierwokupu czy nabycia. O ile nowy wspólnik czy akcjonariusz zainteresowany jest, żeby spółka została zawiadomiona o transakcji, gdyż zależy mu, by wykazać wobec niej swoje prawa, o tyle spółka może przedłużać dokonanie skutecznego nabycia udziałów czy akcji, a nawet blokować je na długi czas, nie przesyłając dokumentów do KOWR i nie zawiadamiając KOWR o przysługujących mu prawach. W celu ochrony praw wspólników oraz akcjonariuszy można zgłosić postulat wprowadzenia do u.k.u.r. takiego terminu. Powyższe uzasadnia także celowość uchylenia obowiązku gromadzenia przez zarząd wskazanych w przepisie dokumentów papierowych w celu wysłania ich do KOWR. 


\section{COMMERCIAL COMPANIES AND THE AMENDED ACT ON THE STRUCTURING OF THE AGRICULTURAL SYSTEM - COMMENTS FROM NOTARIAL PRACTICE}

\section{S u m m a ry}

The article deals with the problems encountered by commercial companies and their partners related to applying the provisions of the Act of 11 April 2003 on the structuring of the agricultural system following the amendment to this Act, which came into force on 26 June 2019. These problems concern the acquisition of agricultural real estate by commercial companies and the disposal of shares and stocks in capital companies already owning such real estate. In the latter case, issues relating to the State Treasury's (the National Agricultural Support Centre) pre-emptive right and the right to acquire shares and stakes are analysed. The problems here relate mainly to the new procedure introduced by the amendment in question, including new obligations for the company's management board.

Furthermore, there is a discussion of the right of the State Treasury to acquire real estate of partnerships in the event of a change of partner or the accession of a new partner to such a company, as well as the new right to acquire the real estate of a company whose shares are permitted for organised trading.

The study advances the thesis that while several facilitating measures have been introduced regarding the acquisition of agricultural real estate by commercial companies, the procedure related to the sale of shares of these companies has been complicated and prolonged to a significant degree. An obligation has been imposed on the management board of a company to collect numerous written documents and send them to the National Centre when the latter has the pre-emptive right or the right to purchase shares or stocks. This impacts negatively on the legal situation of the shareholder whose rights are transferred due to the lack of a deadline by which the company's management board should submit the agreement to the National Centre. At the same time, the new procedure significantly lengthens the proceedings, generates costs and, above all, is completely unnecessary, as most documents are available in an electronic form. The National Centre also has access to the remaining documents. The new regulations have equipped it with the authority to inspect the books and documents of the company whose shares are being sold.

Keywords: right of pre-emption of shares - right to acquire shares - National Support Centre for Agriculture - commercial companies - acquisition of agricultural property

\section{LITERATURA}

Bender P., Podstawowe problemy stosowania znowelizowanej ustawy o kształtowaniu ustroju rolnego (cz. 2), "Rejent” 2019, nr 12.

Bieluk J., Ustawa o ksztattowaniu ustroju rolnego. Komentarz, wyd. 2, Warszawa 2019. 
Bieranowski A., Uwagi o błędnym dekodowaniu zakazu zbywania własności nieruchomości rolnej, „Rejent” 2019, nr 8.

Byczko S., Ustawowe prawo pierwokupu udziałów i akcji spółek będacych właścicielami nieruchomości rolnych, w: Nieruchomości rolne w praktyce notarialnej, pod red. P. Księżaka, J. Mikołajczyk, Warszawa 2017.

Celichowski M., Krótkie omówienie prostej spótki akcyjnej, „Rejent” 2020, nr 8.

Grykiel J., Ograniczenia obrotu nieruchomościami rolnymi oraz prawami udziałowymi w spółkach po nowelizacji ustawy o kształtowaniu ustroju rolnego, "Monitor Prawniczy" 2016, nr 12.

Kremer E., Zgoda Prezesa Agencji Nieruchomości Rolnych jako przesłanka nabycia nieruchomości, "Studia Iuridica Lublinensia” 2017, t. 26, nr 1.

Maj K., Nowelizacja ustawy o kształtowaniu ustroju rolnego obowiazująca od dnia 26 czerwca 2019 r., "Krakowski Przegląd Notarialny” 2019, nr 2.

Maj K., Zmiany w ustawie o kształtowaniu ustroju rolnego obowiązujące od dnia 30 kwietnia 2016 r., „Krakowski Przegląd Notarialny” 2016, nr 2.

Marciniuk K., Zgoda administracyjna jako przesłanka nabycia nieruchomości rolnej, w: Nieruchomości rolne w praktyce notarialnej, pod red. P. Księżaka, J. Mikołajczyk, Warszawa 2017.

Stranz J., Wpływ nowelizacji ustawy o kształtowaniu ustroju rolnego na procedure podwyższenia kapitału zakładowego spółki akcyjnej, "Przegląd Prawa Handlowego" 2016, nr 12. 